\title{
TRADITIONAL CERAMICS IN TECHNOLOGY EDUCATION
}

\section{Igor ŠTUB $\check{N} A$ - Anton TRNÍK - L'ubomíra VALOVIČOVÁ}

\begin{abstract}
Traditional ceramics made from fireclay is very suitable object for imitation of research of ceramics as an educational goal. This material offers a big variety of properties and their measurements with the help of low-cost and simple measurement sets. This can be a good introductory facultative course into material science.
\end{abstract}

Key words: ceramics, school experiment, thermal expansion, modulus of elasticity, mechanical strength.

\section{TRADIČNÁ KERAMIKA VO VUČOVANÍ MATERIÁLOVEDY}

\begin{abstract}
Abstrakt: Tradičná keramika vyrábaná z hliny je vhodný objekt na imitáciu výskumu keramiky. Tento materiál ponúka širokú škálu vlastností, ktoré sa dajú merat' jednoduchými a lacnými prístrojmi. Toto môže byt'vhodným doplnkovým učivom v materiálovedných predmetoch.
\end{abstract}

Klíčová slova: keramika, školský experiment, tepelná roztažnost', modul pružnosti, mechanická pevnost.

\section{Introduction}

The theme of technical materials is generally considered as an essential part of technology education [1]. Perhaps the main reason for this is the fact that each technical object is made from a number of technical materials. The logical consequence of this is that the theme of material is included, or at least, reflected in all curriculums of technical education we have known until now.

Technology education is presently accepted as an integral part of general education. Similarly, a general material science at a basic level can be accepted. Modern human existence is surrounded by an increasing number of materials which enter human life by many ways and in many objects. The understanding of nature and properties of materials can be considered as an organic part of the technical literacy. The number of technical materials is of order of $10^{3}$. It is not possible to include many technical materials as a subject of school teaching. The limited time causes that only main groups of technical materials are taught and students get to be familiar with a particular technical material only in practical use. The main groups usually considered are metal, wood and plastics [2-4].

Ceramics is one of the important materials which is used in many fields. The importance of ceramics grows permanently. It is assumed that ceramics will belong to the most important materials in the 21st century [5-7]. Ceramics is defined as a synthetic material prepared from inorganic raw material powder. Traditional technology is based on forming of the bodies from the wet ceramic mass. The shaped green body undergoes drying and then firing in a kiln where it obtains new properties. There are many arguments for introducing ceramics into technology education. For example, the raw materials for traditional ceramic materials are widespread, they are cheap and the principle of ceramic technology is simple.

There is no chance for ceramics to become a special subject of instruction even in curriculum for technology at pedagogical colleges because of shortage of the time for teaching. Nevertheless, ceramics could be a part of general technology education in primary and secondary schools and in pedagogical colleges. The possibility of this is demonstrated by experience in Germany $[8,9]$.

As ceramics has two stages (dried and fired), for the first level of the elementary school it seems to be optimal to include unfired ceramics only. The accesibility of the raw material (fireclay) and simplicity of preparing of wet mass, giving the required shape and following drying makes it possible to introduce these topics in the basic and/or high schools. Here are many opportunities to observe many important changes, e.g. the change of the wet ceramic mass into dried body during drying and the next change into a final product during firing. These visible changes are characterized by physical properties which can be measured (e.g. dimensions, mass, volume mass, mechanical 
strength, porosity, electrical resistance, ...) before and after drying or firing.

The goal of this paper is to show some examples of including ceramics into the laboratory courses of technology and materials science.

\section{Measurement of mechanical properties}

From mechanical properties of ceramics, the mechanical strengths and Young's modulus are the most suitable values for a measurement. Samples for it have simple form of prism with rectangular cross-section which can be obtain by casting in the gypsum form. To prepare water suspension from fireclay is simple and the right ratio of the fireclay/water can be found experimentally.

The ceramic samples after drying are fragile and their mechanical strength is low. That is just a good property for measuring the mechanical strength in the school conditions, because no complicated apparatus and no big forces must be used. A very simple apparatus for 3-pointbending is described in [10]. For measurement of Young's modulus, a static method is generally used. It exploits simple apparatus, but it is suitable for metallic samples only. For fragile and mechanically week material, the dynamical method is recommended, e.g. a resonant method. This method can be completed from standard measurement units (a.c. $\mathrm{mV}$-meter, RCoscillator) and two electromechanical transducers (exciter and pick-up) made from phonograph cartridges. The principle of the resonant method is explained in $[11,12]$ and the simple apparatus is described in [13]. The method is based on the flexural vibration which can be easily excited and its resonant amplitude is measurable by a common $\mathrm{mV}$-meter. How to separate the resonant frequency of the sample from the false resonances is described in [14].

Since bigger number of samples (e.g. 15) can be easily prepared, a flexural mechanical strength can be measured. If unfired samples are used, a force less than $5 \mathrm{~N}$ suffices for a fracture of the sample with dimensions $5 \times 5 \times 50 \mathrm{~mm}$. Having a set of results, general statistics can be used.

If a laboratory furnace is at disposal, the samples can be fired at difference temperatures. Then variations of the mechanical properties can be measured at the room temperature by the same apparatus as a function of the firing temperature. This partially imitates research of ceramics [15]. Measuring the Young's modulus during heating brings many technical difficulties, so we do not recommend it.

\section{Measurement of coefficient of the linear expansion}

The apparatus for the measurement of the thermal linear expansion of the sample during its heating is relative simple. A modest school apparatus was designed and constructed for a temperature range $20-650{ }^{\circ} \mathrm{C}$ [16]. This method is convenient both for green sample and fired sample. Here is interesting $\alpha \rightarrow \beta$ transformation of quartz which is a permanent part of the fireclay [17].

\section{Conclusion}

Traditional ceramics made from fireclay is very suitable object for imitation of research of ceramics as an educational goal. This material offers a big variety of properties and their measurements with the help of low-cost and simple measurement sets. This can be a good introductory facultative course into material science.

Acknowledgements: This work was supported by the grants VEGA 1/0302/09 and VEGA $1 / 0216 / 09$ and FCVV initiative of the Constantine the Philosopher University under grant I-06-399-01.

\section{References}

[1] KROPÁČ, J.: The common base of material science. In: Proc. of Conf. DIDMATTECH '94, Nitra, 1994, 18-27.

[2] RÁDL, Z., DOLEŽAL, S., JANDA, O.: Technické vzdelávanie - technické práce v 5.triede základnej školy. SPN, Bratislava, 1988 [3] MOŠNA, F. at al.: Technické vzdelávanie technické práce v 6. triede základnej školy., SPN, Bratislava, 1988

[4] ŠKÁRA, I., BREZOVSKÝ, Š., PAVLÍČEK, Ž., Technické vzdelávanie - technické práce $v 7$. triede základnej školy., SPN, Bratislava, 1988

[5] KREMPASKÝ, J.: Prítomnost' a budúcnost' materiálov a technológií. In: Proc. of Conf. DIDMATTECH '93, Nitra, 1993, 4-11

[6] ASHBY, M.F.: Technology for the 1990s: Advanced materials and predictive designe. Phil.Trans.Soc.Lond. A 322 (1987), 393-407

[7] ROUS, B.: Materials for electrical engineering, SNTL, Praha, 1991.

[8] HENZLER, S., LEINS, K.: Technik an Hauptschulen fur die Klassen 5-9, Handwerk und Technik, Hamburg 1987 
[9] HENZLER, S., LEINS, K.: Werken und Gestalten fur die Klassen 5-6, Handwerk und Technik, Hamburg, 1988

[10] ŠTUBŇAa, I., KOZÍK, T., ROHÁČ, J.: Meranie mechanickej pevnosti krehkých materiálov. In: Proc. of Conf. DIDMATTECH '92, Nitra, 1992, 96-99

[11] TRNÍK, A. - ŠTUBŇA, I. LINTNEROVÁ, A.: Measuring the sound velocity in solid materials in laboratory works. In: Proc. 3rd Int. Symp. Material - Acoustic Place 2007, TU Zvolen, 2007, 122-125.

[12] TRNÍK, A, - ŠTUBŇA, I.: Meranie rýchlosti zvuku v tuhých látkach $\mathrm{v}$ laboratórnych cvičeniach. In: Zb. konf. Trendy technického vzdělávání 2005, Votobia Praha, 2005, s. 467470.

[13] TRNÍK, A, - VOZÁR, L. - ŠTUBŇA, I.: Aparatúra na termomechanickú analýzu keramiky. In: Zb. 27. Mezinárdního českého a slovenského kalorimetrického semináre, Svratka 2005, s. 191-194.

[14] VARGA, G. - ŠTUBŇA, I. VÁŽANOVÁ, A. - PODOBA, R. - TRNÍK, A.:
Determination of the vibrating mode of the sample with uniform cross-section. Jemná mechanika a optika, 52, 2007, 334-336.

[15] KOZÍK, T. - ŠTUBŇA, I. - ROHÁČ, J.: Význam fyzikálneho výskumu v technológii keramických materiálov. In. Zb. Rozvoj materiálových véd ve výzkuтu a výuce, Dobřichovice, 1992, s. 33.

[16] ŠTUBŇA, I. - ROHÁČ, J.: Meranie dížkových teplotných zmien tuhých telies školským dilatometrom. Matematika - fyzika informatika, 2, 1992/93, č. 5, s. 252-256.

[17] Spravočnik po proizvodstvu stroitel'noj keramiki. Izd. Literatury po stroitel'stvu, architekture i stroitel'nym materialam, Moskva 1961.

Igor ŠTUBŇA - Anton TRNÍK - L’ubomíra VALOVIČOVÁ

Department of Physics, Constantine the Philosopher University, A. Hlinku 1, 94974 Nitra, Slovakia istubna@ukf.sk, www.ukf.sk 